\title{
Octreotide in variceal bleeding
}

\author{
A K Burroughs
}

\begin{abstract}
Bleeding from oesophageal varices has a high death rate. Injection sclerotherapy is the most appropriate treatment but facilities for this are not always available. Balloon tamponade and vasoactive therapy may be used as stop gap measures. Somatostatin and octreotide are therapeutic candidates for the treatment of variceal bleeding and there are several trials that have compared somatostatin and octreotide with other treatments for this condition. The results of these trials are summarised and discussed. A meta analysis of the group of trials of placebo or $\mathrm{H}_{2}$ antagonists $v$ somatostatin or octreotide showed a significant advantage of somatostatin or octreotide in terms of efficacy, but no difference in mortality. The trials discussed seem to show that somatostatin and octreotide are at least as effective as other treatments, with the benefit of fewer adverse effects, and thus represent the best vasoactive agents. Additionally, they may have a role as adjuvant treatment to emergency sclerotherapy for active bleeders and this must be further investigated.

(Gut 1994; supplement 3: S23-S27)
\end{abstract}

Bleeding from oesophageal varices is a medical emergency that still has a high mortality, about $20-25 \%$, depending on the severity of the underlying liver disease. ${ }^{12}$ Bleeding is often massive. A particular feature of variceal bleeding is the frequency of very early rebleeding, which is a prognostic factor for death (as for peptic ulcer bleeding). Emergency treatment follows the same principles as for other types of gastrointestinal bleeding and consists of resuscitation, diagnosis, and control of bleeding. Most patients in the developed world have underlying cirrhosis, so that non-surgical options are favoured as first line treatments, because the operative mortality in cirrhotic patients is high. ${ }^{3}$ These options include vasoactive drugs, balloon tamponade, endoscopic injection sclerotherapy, banding ligation of oesophageal varices or a combination of these treatments. The aims of treating acute variceal bleeding are to control the haemorrhage, prevent early rebleeding, minimise the deterioration in liver function, and treat complications associated with blood loss.

In the last 15 years, endoscopic sclerotherapy has gained popularity as an emergency treatment for the control of acute variceal haemorrhage, achieving primary haemostasis in $70 \%$ with one injection session and up to $95 \%$ with two sessions. ${ }^{4}$ The facilities for injection sclerotherapy, however, are not always available nor is the expertise required to inject a copiously bleeding varix. Consequently, in most centres, stop gap treatment such as balloon tamponade of the oesophagus or vasoactive therapy, or both, remain the first line treatment for acute variceal haemorrhage. Injection sclerotherapy or other definitive treatment is often delayed until the bleeding is controlled and the patient stable. Alternatively, the patient can be transferred to a referral centre when stable for definitive treatment.

Balloon tamponade of the oesophagus is effective in controlling acute variceal bleeding in about $70-80 \%$ of patients. Recurrent bleeding, however, occurs rapidly in roughly half of these patients and the complication rate of $15-20 \%$ is unacceptably high. ${ }^{5}$ An important consideration is that it is an uncomfortable and unpleasant experience for the patient. Consequently, if given the choice, most patients with bleeding oesophageal varices would prefer effective vasoactive treatment to balloon tamponade.

Additionally vasoactive drug therapy is the only treatment that does not require special skill and is immediately available. There is recent evidence that patients who continue to bleed or rebleed early are those with high variceal or portal pressures. ${ }^{67}$ This suggests that use of a vasoactive drug over several days is of potential therapeutic benefit.

\section{VASOPRESSIN OR GLYPRESSIN WITH OR} WITHOUT NITROGLYCERIN

Since its introduction in 1956 and until recently, vasopressin has remained the vasoactive treatment most widely used for the control of acute variceal bleeding. Of the 336 episodes of variceal bleeding treated with vasopressin in the 17 randomised clinical trials published to date, however, control of haemorrhage was only achieved in 145 instances, a success rate of less than $50 \% .^{8-24}$ In addition to doubts regarding its efficacy, vasopressin is associated with side effects in about $25 \%$ of the patients, several of which require withdrawal of treatment and some of which can be fatal. To minimise the side effects and enhance the vasoactive effects of the drug, two new therapeutic approaches using vasopressin have been proposed. The first entails the use of a vasopressin analogue, triglycyl-lysine vasopressin (terlipressin or glypressin), which has some biological activity in itself but is enzymatically cleaved in vivo to lysine vasopressin. Placebo controlled trials have shown glypressin to be effective. ${ }^{2526}$ The second approach entails concomitant administration of nitroglycerin. The rationale for this treatment is that nitroglycerin does not change the effects of vasopressin on portal pressure, but 
prevents many of the systemic side effects particularly on the coronary circulation. Controlled clinical trials with glypressin ${ }^{14-27}$ or combined vasopressin nitroglycerin ${ }^{18} 19$ treatment show that these treatments are associated with fewer side effects than vasopressin. An increased efficacy, however, of glypressin or combined vasopressin-nitroglycerin treatment over vasopressin alone has not been proved. The magnitude of splanchnic haemodynamic effects in terms of portal pressure reduction is variable, with little effect in some patients. ${ }^{28}$

\section{Somatostatin and octreotide}

Somatostatin is a 14 amino acid peptide that was found to reduce splanchnic blood flow in normal humans. ${ }^{29-31}$ In stable cirrhotic patients modest reductions in hepatic blood flow $^{32}$ and wedged venous pressure ${ }^{33-36}$ have been reported by several groups, but others have found no effect on portal pressure ${ }^{32} 37$ or intravariceal pressure. ${ }^{38}$ Azygos blood flow, a measure of collateral blood flow including variceal flow, has, however, always been shown to fall with somatostatin, and more noticeably than with vasopressin for a similar reduction in portal pressure. ${ }^{36}$

Octreotide is a synthetic octapeptide of somatostatin (sharing four amino acids with somatostatin that are responsible for biological activity), which has similar pharmacological effects as the naturally occurring hormone but a considerably longer duration of action. Like somatostatin, octreotide significantly reduces portal pressure in experimental animals ${ }^{39} 40$ and in patients with portal hypertension ${ }^{41} 42$ after either an intravenous bolus administration or a continuous infusion. Subcutaneous administration produces a sustained reduction in portal pressure in rats with cirrhosis and portal hypertension. ${ }^{39}$ Perhaps more importantly with respect to the control of the acute variceal bleed, the effects of octreotide on collateral blood flow ${ }^{40}$ and azygos blood flow ${ }^{43}$ are significantly greater than its effect on portal pressure in experimental animals and patients with cirrhosis and portal hypertension.

Octreotide has similar effects to somatostatin in stable cirrhotic patients (not bleeding), with little or no effect on wedged hepatic venous pressure, ${ }^{44} 45$ variable effects on intravariceal pressure, ${ }^{38} 46$ but a significant reduction in azygos blood flow. ${ }^{43} 4447$ Bolus octreotide $(25 \mu \mathrm{g})$ transiently but significantly reduces cardiac output in stable cirrhotic patients whereas a $50 \mu \mathrm{g} /$ hour infusion had less noticeable effects. These effects are not clinically manifest during the studies. ${ }^{48}$ It suggests that constant infusion rather than bolus injection is the optimal route of administration. A recent report on somatostatin and renal function in cirrhosis suggests it may adversely affect renal function. ${ }^{49}$ The study was performed, however, under volume loading, which may have changed the balance of effects on endogenous vasodilators and the renin, angiotensin, and aldosterone system. ${ }^{50}$ Another study in which no volume loading was given suggests a beneficial effect of octreotide on renal function. ${ }^{51}$ In an animal model octreotide improves salt and water excretion. ${ }^{52}$ In all the clinical trials reported there are no reports of adverse effects on renal function of somatostatin or octreotide and no differences compared with the other treatment(s) evaluated in the trials.

The variability in splanchnic haemodynamic effects, particularly for portal pressure reduction, have led most clinicians to consider somatostatin or octreotide as unlikely therapeutic candidates to treat variceal bleeding. Although the reduction in azygos blood flow may be the important haemodynamic effect for the control of variceal bleeding, there is no proof that this is so. The effects on splanchnic haemodynamics, however, should be tempered by several considerations when considering the results of therapeutic efficacy in various trials of vasoactive drugs in portal hypertension. Firstly, in cirrhotic patients the variability in splanchnic haemodynamic effects in response to any vasoactive drug probably reflects normal biological variability or possibly variability because of as yet unknown pathophysiological differences among patients. This variability has been shown with vasopressin and propranolol, drugs used for the acute control and prevention of variceal bleeding respectively. It is now accepted that both these drugs have some therapeutic effect despite the variability in haemodynamic responses. As mentioned above, the therapeutic effect with vasopressin is modest and accompanied by many side effects. With propranolol, the therapeutic effect on rebleeding is also modest but with no serious side effects. In a primary prophylactic study, patients taking propranolol (or placebo) who did not reduce their hepatic venous pressure gradient to less than $12 \mathrm{~mm} \mathrm{Hg}$ were shown to have more chance of bleeding. ${ }^{53}$ The second consideration is that the dosage schedules of somatostatin in both research protocols and clinical studies have been largely empirical, usually giving a single bolus followed by an infusion. The third consideration is that the effects of somatostatin or octreotide and other vasoactive drugs during variceal bleeding may be quantitatively different from those seen in stable cirrhotic patients reported in haemodynamic studies, as patients present a different haemodynamic profile when bleeding, both in the splanchnic and systemic circulation, in comparison with stable patients. Thus, evidence for therapeutic efficacy must be sought in the results of clinical trials.

There are several trials that have compared somatostatin and octreotide with other treatment for acute variceal bleeding 15 16 21-24 54-66 (Table). Apart from the trial by Walker et al, ${ }^{63}$ in which the side effects attributed to octreotide do not seem directly related, all studies show significantly fewer side effects with somatostatin and octreotide compared with the other therapies. ${ }^{15} 16$ 21-24 54-66 Moreover, no patient required withdrawal of somatostatin or octreotide because of side effects, unlike the case with vasopressin.

The two double blind placebo controlled trials of somatostatin unfortunately give 
Randomised clinical trials of somatostatin or octreotide ${ }^{\star}$ for the emergency treatment of variceal bleeding

\begin{tabular}{|c|c|c|c|c|c|}
\hline $\begin{array}{l}\text { Author } \\
\text { (reference) }\end{array}$ & $\begin{array}{l}\text { Date } \\
\text { of } \\
\text { publication }\end{array}$ & $\begin{array}{l}\text { Patients } \\
\text { or patient } \\
\text { admissions }\end{array}$ & $\begin{array}{l}\text { Duration } \\
\text { of } \\
\text { treatment }\end{array}$ & $\begin{array}{l}\text { Efficacy of } \\
\text { somatostatin } \\
\text { or octreotide } \\
(\%)\end{array}$ & Other treatment (\%) \\
\hline 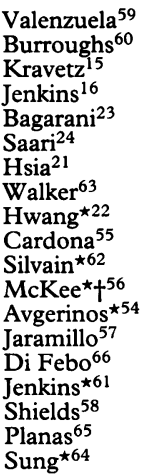 & $\begin{array}{l}1989 \\
1990 \\
1984 \\
1985 \\
1987 \\
1990 \\
1990 \\
1992 \\
1992 \\
1989 \\
1991 \\
1990 \\
1991 \\
1991 \\
1990 \\
1992 \\
1992 \\
\text { In press } \\
1993\end{array}$ & $\begin{array}{r}84 \\
120 \\
61 \\
22 \\
50 \\
54 \\
46 \\
50 \\
48 \\
38 \\
50 \\
40 \\
92 \\
39 \\
47 \\
40 \\
80 \\
45 \\
65\end{array}$ & $\begin{array}{l}30 \text { hours } \\
5 \text { days } \\
48 \text { hours } \\
24 \text { hours } \\
48 \text { hours } \\
72 \text { hours } \\
24 \text { hours } \\
24 \text { hours } \\
24 \text { hours } \\
24 \text { hours } \\
24 \text { hours } \\
48 \text { hours } \\
24 \text { hours } \\
<24 \text { hours } \\
48 \text { hours } \\
48 \text { hours } \\
5 \text { days } \\
48 \text { hours } \\
48 \text { hours }\end{array}$ & $\begin{array}{r}65 \\
64 \\
53 \\
100 \\
67 \\
66 \\
55 \\
68 \\
63 \\
45 \\
86 \\
50 \\
71 \\
58 \\
78 \\
90 \\
77 \\
82 \\
72\end{array}$ & $\begin{array}{l}83 \text { (placebo) } \\
41 \text { (placebo) } \\
58 \text { (vasopressin) } \\
33 \text { (vasopressin) } \\
32 \text { (vasopressin) } \\
52 \text { (vasopressin) } \\
38 \text { (vasopressin) } \\
80 \text { (glypressin) } \\
46 \text { (vasopressin) } \\
55 \text { (vasopressin/nitroglycerin) } \\
62 \text { (glypressin/nitroglycerin) } \\
70 \text { (tamponade) } \\
80 \text { (tamponade) } \\
50 \text { (tamponade) } \\
92 \text { (sclerotherapy) } \\
90 \text { (sclerotherapy) } \\
80 \text { (sclerotherapy) } \\
87 \text { (sclerotherapy) } \\
58 \text { (sclerotherapy) }\end{array}$ \\
\hline
\end{tabular}

†Efficacy was also assessed in a third group given combined somatostatin and balloon tamponade. balloon tamponade (one with octreotide) 545657 there was no statistically significant difference in efficacy or mortality. In the group of four trials $v$ sclerotherapy, ${ }^{58616566}$ there was no statistical difference in efficacy or mortality between somatostatin or octreotide and injection sclerotherapy. Moreover, a recent trial of octreotide $v$ sclerotherapy by Sung et al, 64 performed in a skilled endoscopic unit, showed no differences in control of bleeding, early rebleeding, blood product use, or mortality between the two treatments.

Given that emergency sclerotherapy is now commonly used to control variceal bleeding irrespective of concomitant vasoactive treatment, it is reasonable to use it for active bleeding at endoscopy, as it permits a therapeutic measure to be given at initial diagnostic endoscopy. Indeed the Athens 1992 meta analysis (Burroughs, unpublished results) examined all trials of vasoactive drugs with or without use of balloon tamponade $v$ injection sclerotherapy and showed the second to have a statistically significant advantage in terms of efficacy and mortality. There is always an interval before endoscopy, however, so that sclerotherapy cannot be given immediately. Occasionally bleeding is so severe that visibility is obscured. Sometimes the patient cannot safely have endoscopy without an endotracheal tube because of the dangers of aspiration. Thus, an active drug that might 'hold' the bleeding in the interval before endoscopy or facilitate sclerotherapy, or both, by stopping active bleeding would be of great clinical use.

Recent studies of portal pressure ${ }^{7}$ in the first 48 hours after admission for variceal bleeding have shown that 'difficult' bleeders - that is, those who seem to continue to bleed or have early variceal rebleeding - have a higher portal pressure. The studies were small so that it was difficult to establish a threshold pressure for an increased risk of 'uncontrolled' bleeding, but when the hepatic venous pressure gradient fell to below $16 \mathrm{~mm} \mathrm{Hg}$, there was a much smaller risk of rebleeding. Studies of intravariceal pressure show that it closely varies with central venous pressure and a lower pressure results in less early rebleeding. ${ }^{6}$ Thus, there is a good rationale for using vasoactive drugs for the initial treatment of variceal bleeding but also to keep a portal hypotensive effect for several days, when the risk of rebleeding is most common.

The clinical trials performed to date suggest that both octreotide and somatostatin are at least as effective as the conventional vasoactive drugs, balloon tamponade, and injection sclerotherapy in the treatment of variceal haemorrhage with the advantage of fewer side effects. Thus, they represent the best vasoactive agents pending further trials. Most importantly, however, these drugs need to be assessed as adjuvant treatment to emergency sclerotherapy for active bleeders. (Table) there were no statistical differences in either efficacy or mortality and the results were virtually identical. As already mentioned, however, every trial apart from that by Walker et $a l^{63}$ had a statistically significant reduction in complication rate in the groups treated with somatostatin or octreotide. In the three trials $v$
1 Graham DY, Smith JL. The course of patients after variceal hemorrhage. Gastroenterology 1981; 80: 800-9.

2 Burroughs AK, Mezzanotte G, Phillips A, McCormick PA, McIntyre N. Cirrhotics with variceal hemorrhage: the importance of the time interval between admission and the start of analysis for survival and rebleeding rates. Hepatology 1989; 9: 801-7. 
3 Spence RAJ. Surgical measures for active variceal bleeding Gastrointestinal Endoscopy Clinics of North America 1992; $77-94$

4 Westaby D. Emergency and elective endoscopic therapy for variceal haemorrhage. Ballieres Clin Gastroenterol 1992; 6 465-80.

5 Vlavianos P, Gimson AE, Westaby D, Williams R. Balloon tamponade in variceal bleeding: use and misuse. $B M F$ 1989; 298: 1158-9.

6 Del Arbol LR, de Argila M, Vasquez C, et al. Endoscopic measurement of variceal pressure (VP) during haemorrhage from esophageal varices (HEV). Hepatology 1992; 6: $81 \mathrm{~A}$.

7 Ready JB, Robertson AD, Gaff JS, Rector WG Jr. Assessment of the risk of bleeding from esophageal varices by continuous monitoring of portal pressure. by continuous monitoring of

8 Clanet J, Tournut R, Fouetanier C, et al. Traitement par la pitressine des hémorragies par rupture de varices oesophagiennes chez le cirrhotique. Acta Gastroenterol Belg 1978; 41: 539-43.

9 Correia JP, Alves MM, Alexandrio P, Silveira J. Controlled trial of vasopressin and balloon tamponade in bleeding esophageal varices. Hepatology 1984; 4: 885-8.

10 Merigan TC Jr, Plotkin JR, Davidson CS. Effect of intravenously administered posterior pituitary extract on hemorrhage from bleeding esophageal varices. $N$ Engl $f$ Med 1962; 266: $134-5$.

11 Johnson WC, Wildrich WC, Ansell JE, et al. Control of bleeding varices by vasopressin: a prospective randomized study. Ann Surg 1977; 186: 369-76.

12 Chojkier M, Groszmann RJ, Atterbury CE, et al. A controlled comparison of continuous intraarterial and intravenous infusions of vasopressin in hemorrhage from esophageal varices. Gastroenterology 1979; 77: 540-6.

13 Fogel MR, Knaver M, Andress LL. Continuous intravenous vasopressin in active upper gastrointestinal bleeding. A placebo-controlled trial. Ann Intern Med 1982; 96: 565-9.

14 Freeman JG, Lishman AH, Cobden I, Record CO. Controlled trial of terlipressin ('Glypressin') versus vasopressin in the early treatment of oesophageal varices. Lancet 1982; ii: $266-8$.

15 Kravetz D, Bosch J, Terés J, et al. Comparison of intravenous somatostatin and vasopressin infusions in treatment of acute variceal hemorrhage. Hepatology 1984; 4: $442-6$

16 Jenkins SA, Barter JN, Corbett W, et al. A prospective randomised controlled clinical trial comparing somatostatin and vasopressin in controlling acute variceal haemorrhage. $B M 7$ 1985; 290: 275-8.

17 Conn HO, Ramsby GR, Storer EH, et al. Intraarterial vasopressin in the treatment of upper gastrointestinal hemorrhage: a prospective, controlled clinical trial. Gastroenterology 1975; 68: 211-21.

18 Tsai YT, Lay CS, Lai KH, et al. Controlled trial of vasopressin plus nitroglycerin vs vasopressin alone in the vasopressin plus nitroglycerin vs vasopressin alone in the
treatment of bleeding esophageal varices. Hepatology treatment of

19 Gimson AES, Westaby D, Hegart J, et al. A randomized trial of vasopressin and vasopressin plus nitroglycerin in the control of acute variceal hemorrhage. Hepatology 1986; 6 : $410-3$.

20 Mallory A, Schaefer JW, Cohen JR, et al. Selective intraarterial vasopressin infusion for upper gastrointestina tract hemorrhage. A controlled trial. Arch Surg 1980; 115: $30-2$

21 Hsia H-C, Lee F-Y, Tsai Y-T, et al. Comparison of somatostatin and vasopressin in the control of acute esophageal variceal hemorrhage: a randomized controlled study. Clin 7 Gastroenterol 1990; 7: 71-8.

22 Hwang S-J, Lin H-C, Chang C-F, et al. A randomized controlled trial comparing octreotide and vasopressin in the control of acute esophageal variceal bleeding. $f$ Hepatol 1992; 16: 320-5.

23 Bagarani M, Albertini V, Anza M, et al. Effect of somatostatin in controlling bleeding from esophageal varices. Ital F Surg Sci 1987; 17: 172-6.

24 Saari A, Klvilaakso E, Inberg $M$, et al. Comparison of somatostatin and vasopressin bleeding esophageal varices. Am $\mathcal{F}$ Gastroenterol 1990; 85: 804-7.

25 Soderlund C, Magnusson I, Torngren S, Lundell L. Terlipressin (triglycyl-lysine vasopressin) controls acute bleeding oesophageal varices. A double-blind, randomised, placebo-controlled trial. Scand $\mathcal{F}$ Gastroenterol domised, placebo-co

26 Freeman JG, Cobden I, Record CO. Placebo-controlled tria of terlipressin (glypressin) in the management of acute variceal bleeding. $\mathcal{F}$ Clin Gastroenterol 1989; 11: 58-60.

27 Walker S, Stiehl A, Raedshc R, Kommerell B. Terlipressi in bleeding esophageal varices: a placebo controlled double-blind study. Hepatology 1986; 6: 112-5.

28 Bosch J, Teres J. Immediate management of variceal hemorrhage. Gastrointestinal Endoscopy Clinics of North America 1992; 2: 43-58.

29 Wahren J, Felig P. Influence of somatostatin on carbohydrate disposal and absorption in diabetes mellitus. Lancet 1976; ii: 1213-6.

30 Sonnenberg GE, Keller U, Perruchud A, et al. Effect of somatostatin on splanchnic hemodynamics in patients with cirrhosis of the liver and in normal subjects. Gastroenterology 1981; 80: 526-32.

31 Tyden G, Samnegaard H, Thulin L, Muhrbeck O, Efendic $S$. Circulatory effects of somatostatin in anesthetized man. Acta Chir Scand 1979; 145: 443-6.
32 Merkel C, Gatta A, Zuin R, Finucci GF, Arnaboldi L, Roul A. Effect of somatostatin on splanchnic hemodynamics in patients with liver cirrhosis and portal hypertension. Digestion 1985; 32: 92-8.

33 Bosch J, Kravetz D, Rodes J. Effects of somatostatin on hepatic and systemic hemodynamics in patients with cirrhosis of the liver: comparison with vasopressin. Gastroenterology 1981; 80: 518-25.

34 Bories P, Pomier-Layrargues G, Chotard JP, Jacob C, Michel $\mathrm{H}$. Somatostatin reduces portal hypertension in cirrhotic patients. Gastroenterol Clin Biol 1980; 4: 616-7.

35 Eriksson LS, Law DH, Sato Y, Wahren J. Influence of somatostatin on splanchnic haemodynamics in patients with liver cirrhosis. Clin Physiol 1984; 4: 5-11.

36 Mastai R, Bosch J, Navasa M, et al. Effect of continuous infusion and bolus injections of somatostatin (SMT) on azygos blood flow and hepatic and systemic hemodynamics in patients with portal hypertension, comparison with vasopressin. $\mathcal{F}$ Hepatol 1986; 3 (suppl 1): S53.

37 Sonnenberg A, West C. Somatostatin reduces gastric mucosal blood flow in normal subjects but not in patients with cirrhosis of the liver. Gut 1983; 24: 148-53.

38 Kieber G, Sauerbruch T, Fischer G, Paumgartner G. Somatostatin does not reduce oesophageal variceal pressure in liver cirrhotics. Gut 1988; 29: 153-6.

39 Jenkins SA, Barter JN, Corbett WA, Shields R. The effects of a somatostatin analogue SMS 201-995 on hepatic haemodynamics in the cirrhotic rat. Br f Surg 1985; 72: 864-7.

40 Jenkins SA, Barter JN, Corbett WA, Shields R. Effects of a somatostatin analogue SMS 201-995 on hepatic haemodynamics in the pig and on intravariceal pressure in man. Br f Surg 1985; 72: 1009-12.

41 Jenkins SA, Barter JN, Snowden S, Whitehouse G, Shields $R$. The effect of somatostatin and SMS 201-995 on hepatic and systemic haemodynamics in patients with cirrhosis and portal hypertension. Fibrinolysis 1988; 2: 48-50.

42 McKee RK, Pringle SD, Garden OJ, et al. SMS 201-995 in the management of variceal bleeding. Gut 1987; 28: A1380.

43 Navasa $M$, Bosch J, Chesta J, et al. Haemodynamic effects of subcutaneous administration of SMS 201-995, a long acting somatostatin analog, in patients with cirrhosis and portal hypertension. Hepatology 1988; 7: S64

44 Eriksson LS, Brundin T, Soderlund C, Wahren J. Haemodynamic effects of a long-acting somatostatin analogue in patients with liver cirrhosis. Scand $f$ Gastroenterol 1987; 22: 919-25.

45 Pringle SD, McKee RF, Garden OJ, et al. The effect of a long-acting somatostatin analogue on portal and systemic haemodynamics in cirrhosis. Aliment Pharmacol Therap 1988; 2: 451-9.

46 Primignani $M$, Nolte A, Vazzoler $M$, et al. The effect of octreotide on intra oesophageal variceal pressure (IOVP) in liver cirrhosis is unpredictable [Abstract]. Hepatology 1990; 12: 989 .

47 McCormick PA, Dick R, Siringo S, et al. Octreotide reduces azygos blood flow in cirrhotic patients with portal hypertension. Eur f Gastroenterol Hepatol 1990; 2: 489-92.

48 McCormick P, Chin J, Greenslade L, et al. Systemic haemodynamic effects of intravenous octreotide in patients with cirrhosis. Gut 1993; 34 (suppl 1): S42.

49 Gines A, Salmeron J, Gineys P, et al. Effects of somatostatin on renal funct

50 Dudley FJ. Somatostatin and portal hypertensive bleeding: a safe therapeutic alternative? Gastroenterology 1992; 103: 1973-7.

51 Mountokalakis $\mathrm{T}$, Kallivretakis N, MayopoulouSymvoulidou D, et al. Enhancement of renal function by a long-acting somatostatin analogue in patients with decompensated cirrhosis. Nephrol Dial Transplant 1988; 3: 604-7.

52 Albillos A, Colombato L, Lee F-Y, Groszmann RJ. Octreotide ameliorates vasodilatation and $\mathrm{Na}+$ retention in portal hypertensive rats. Gastroenterology 1993; 104: 575-9.

53 Groszmann RJ, Bosch J, Grace ND, et al. Hemodynamic events in a prospective randomized trial of propranolol versus placebo in the prevention of a first variceal hemorrhage. Gastroenterology 1990; 99: 1401-7.

54 Avgerinos A, Kionis C, Rekoumis G, et al. A prospective randomized trial comparing somatostatin, balloon tamponade and the combination of both methods in the tamponade and the combination of both methods in the
management of acute variceal haemorrhage. $\mathcal{F}$ Hepatol

55 Cardona C, Vida F, Balanzó J, et al. Eficacia terapéutica de la somatostatina versus vasopresina más nitroglicerina en a hemorragia activa por varices esofagogástricas. Gastroenterologia y Hepatologia 1989; 12: 30-4.

56 McKee R. A study of octreotide in oesophageal varices. Digestion 1990; 45 (suppl 1): 60-5.

57 Jaramillo JL, de la Mata M, Mino G, et al. Somatostatin versus Sengstaken balloon tamponade for primary haemostasia of bleeding esophageal varices. A randomized pilot study. F Hepatol 1991; 12: 100-5.

58 Shields R, Jenkins SA, Kingsworth AN, et al. A prospective randomised controlled trial comparing the efficacy of somatostatin with injection sclerotherapy in the control of bleeding oesophageal varices. $\mathcal{F}$ Hepatol 1992; 16: 128-37.

59 Valenzuela JE, Schubert T, Fogel MR, et al A multicenter, randomized, double-blind trial of somatostatin in the management of acute hemorrhage from esophageal varices. Hepatology 1989; 10: 958-61. 
60 Burroughs $\mathrm{AK}, \mathrm{McC}$ Cormick PA, Hughes MD, et al. Randomized, double-blind, placebo-controlled trial of somatostatin for variceal bleeding: emergency control and prevention of early variceal rebleeding. Gastroenterology prevention of early

61 Jenkins SA, Copeland G, Kingsworth A, Shields R. A prospective randomized controlled clinical trial comparing sandostatin and injection sclerotherapy in the control of acute variceal haemorrhage: an interim report. Gut 1992; 33 (suppl 1): S56.

62 Silvain C, Carpentier S, Savtereau D, et al. A randomized trial of glypressin plus transdermal nitroglycerin versus octreotide in the control of acute variceal hemorrhage. Hepatology 1991; 14: 133A.
63 Walker S, Kreichgauer H-P, Bode JC. Terlipressin vs somatostatin in bleeding esophageal varices: a controlled, double-blind study. Hepatology 1992; 15: 1023-30.

64 Sung JY, Chung S, Lai CW, et al. Octreotide infusion or emergency sclerotherapy for variceal haemorrhage. Lancet 1993; 342: 637-41.

65 Planas R. Randomized trial of somatostatin versus sclerotherapy in cirrhotic patients. Gastroenterology (in press)

66 Di Febo G, Siringo S, Vacirca M, et al. Somatostatin (SMS) and urgent sclerotherapy (US) in active oesophagea variceal bleeding. Gastroenterology 1990; 98: A583.

67 Cardin F, Gori G, McCormick PA, Burroughs AK. A predictive model for very early rebleeding from varices. Gut 1990; 31: A1204. 